\title{
Poetry and the Respublica Litterarum in the Sixteenth Century. The Communication of Ideas: George Buchanan and Jan Kochanowski
}

\author{
ELWIRA BUSZEWICZ
}

Jagiellonian University in Krakow

Jan Kochanowski, le poète le plus important de la Renaissance polonaise, loue les Paraphrases des Psaumes de George Buchanan dans son épigramme élogieux intitulé Ad Buchananum. Il s'agit du seul ouvrage dans lequel Kochanowski s'adresse directement au grand humaniste écossais. On ne trouve pourtant aucune preuve que les deux poètes se sont rencontrés en personnes. Toutefois, Kochanowski a voyagé en Italie entre 1552 et 1559, et est passé par Paris lors de son retour en Pologne. Les Paraphrases des Psaumes de Buchanan ont profondément inspiré le Psautier de Kochanowski, qui ouvre une nouvelle voie au discours poétique polonais. Il semble d'ailleurs que d'autres poèmes de Kochanowski ont été marqués par cette influence. On note un nombre important de convergences significatives dans les vers latins de Kochanowski, par exemple, dans son Foricenia (une collection d'épigrammes), dans lequel le poète polonais exprime son idéal $d u$ "poète amateur de vin ». On trouve la même inspiration dans son Lyricorum libellus, dans lequel se trouve une ode intitulée In equum qui semble avoir été conçue comme la contrepartie de De equo elogium de Buchanan. Parmi d'autres exemples, deux monologues pastoraux de Kochanowski (Dryas Zamchana, Pan Zamchanus) interprétés en présence du roi de Pologne, semblent inspirés par le Pompae deorum rusticorum. Cet article met en lumière ces similitudes, bien qu'il ne soit pas possible de prouver hors de tout doute qu'il s'agit d'un véritable dialogue littéraire ou de l'effet d'un courant humaniste. Néanmoins, ces similitudes pourraient être considérées comme des marques de la communication des idées au sein de la République des Lettres.

$\mathrm{H}$ istorians of Polish literature are unanimous in considering Jan Kochanowski (1530-84) the most brilliant poet of the Polish Renaissance. Marian Kamil Dziewanowski calls him "Poland's prince of poets" and "the 
Polish Ronsard." Kochanowski wrote both in Latin and in the vernacular, but even his Latin muse is relatively little known by Western scholars. His vernacular poetry played a fundamental role in developing Polish verse and became a paradigm of poetic composition and a source of inspiration as well. ${ }^{2}$ As Adam Karpiński points out, "One of the most difficult tasks faced by today's literary historian is to explain the phenomenon and universality of Kochanowski's poetry, which soared to artistic heights pioneered by the ancient tradition and Renaissance poetics, yet was at the same time received by readers-at-large as 'their own'."3 Although Kochanowski's literary work was undoubtedly inspired by ancient authors, neo-Latin writers also had their part as his sources and models. Buchanan's impact upon his poetry, both Latin and vernacular, seems self-evident; it is also manifold, even if Polish scholars have observed it primarily in Kochanowski's Psalter, in which the poet not only follows some of Buchanan's interpretative, rhetorical, and metrical solutions ${ }^{4}$ but also seems to apply similar ideas in his vernacular verse as Buchanan does in his Latin paraphrases of the Psalms. There is no evidence that the two poets ever met. Nevertheless, some scholars have taken into consideration the possibility of their interpersonal contact. Kochanowski was in Italy between 1552 and 1559, and finally returned to Poland via Paris; probably the poet's guide in France, the "Carolus" to whom he addressed his Elegy III 8, may indeed be identified as Karel Utenhove Minor. ${ }^{5}$ That "Carolus" accompanied the poet during the iter Gallicum and also Belgicum is told in the elegy below:

Nam mihi magnus amor tuaque est perspecta voluntas,

Hospes in externis dum vagus erro locis.

Te duce Aquitanos et Belgica vidimus arva,

Extremoque sitam littore Massiliam.

Celtarumque domos, et qua magnae influit urbi

Caeruleus rapidis Sequana vorticibus.

Hic illum patrio modulantem carmina plectro

Ronsardum vidi, nec minus obstupui,

Quam si Thebanos ponentem Amphiona muros,

Orpheave audissem Phoebigenamve Linum.

Delinita suos inhibebant flumina cursus,

Saxaque ad insolitos exsiluere sonos. ${ }^{6}$ 
(For I have seen your friendship and good will,

When I was wandering as a pilgrim in foreign lands.

Under your guidance I saw Aquitania and the fields of Belgium,

And Marseilles, located on the extreme coast,

And also the habitations of the Celts and the place where the Seine

Flows rapidly through a great city;

There I saw Ronsard, who sang his poems with the vernacular lyre

And I stood so amazed,

As if I had been listening to Amphion building the walls of Thebes,

Or Orpheus, or Linus, son of Phoebus.

At this extraordinary sound the rivers stopped their course,

And the stones jumped up. $)^{7}$

Utenhove, un ami gantois de la Pléiade, ${ }^{8}$ was also Buchanan's close friend and thus might have attracted Kochanowski's notice to the Scotsman's literary activity; he might even have been able to arrange a personal meeting with him in Paris. Upon Stephanus's edition of Davidis psalmi aliquot Latino carmine expressi a quatuor illustribus poetis (Paris, 1556), Kochanowski may have learned of Buchanan's art of paraphrase and studied his technique (the anthology contained "the primeurs" of eighteen of Buchanan's paraphrases). And, as the anthology was a kind of "agon" competition, he may have also learned that it was compared to the work of other psalmodists. ${ }^{10}$ Therefore, by the time he arrived in Paris, the idea of Buchanan's supremacy among the neo-Latin poets who composed paraphrases of the Psalms had probably already come to Kochanowski's mind; however, it seems reasonable to suppose that the short poem in which he expressed his admiration for the Scots humanist was not written until after the first complete edition of the Psalmorum Davidis paraphrasis poetica (1566) had appeared. In the epigram which was to be incorporated as number 68 in his collection of Foricenia, Kochanowski addresses Buchanan directly, but such literary communication was not unusual in the Respublica litterarum, even if the two correspondents had never met.

\section{Ad Buchananum}

Solvisti cura et longo, Buchanane, labore

Omnes qui vatum nomen habere student, $\mathrm{Ne}$ incassum certent Solymaei carmina regis 
Aptare ad Latiae fila canora lyrae;

nam quicumque opus hoc aggressi aliquando fuerunt,

Tanto intervallo tu, Bucanane, praeis

Omnibus, ut veniens aetas quoque non videatur

Ereptura tuis hoc decus e manibus. ${ }^{11}$

(Buchanan! You have released from trouble and long labour

All these who want to be renowned poets.

Let them not try to adapt (in vain) the King of Jerusalem's psalms

To the sound of the Latin lyre's strings,

Because all those who have ventured on this task

Have been overcome by you, Buchanan, to such an extent

That even in the future, it seems,

The leadership will not be wrenched from your hands.)

The epigram suggests that Buchanan reached a virtually unattainable ideal in his paraphrases of the Psalms, creating a near-perfect work. ${ }^{12}$ In this situation it would be inept of Kochanowski to embark on poetic imitation by writing psalms in Latin. Since his Italian and French experience had taught him about the increasing role of vernacular poetry, he undertook the challenge of emulation by paraphrasing the Psalter in Polish, re-composing it as a series of Horatian hymnic odes and following Buchanan's metrical varietas. ${ }^{13} \mathrm{He}$ was also inspired by certain ideas and forms from Buchanan's psalms, which could be considered not only as hymns and prayers, but also as reflective odes embedded in the rhetorical genus deliberativum that recommended the ethical model of the Renaissance man of virtue (and the Christian Everyman ${ }^{14}$ as well) and highlighted the emotional variability in the human individual. Thus, his emulation of Buchanan resulted in a collection of Psalm paraphrases in Polish verse structures reminiscent of Horatian odes. However, although Kochanowski observed some Horatian similia in Buchanan's Psalter, he did not follow Buchanan slavishly but, carefully selecting words and verses, found his own solutions and made decisions on his own. Buchanan's psalms seem to have inspired not only Kochanowski's Psalter, but probably also his other vernacular poems; the most representative of them may be the last from the collection of his Threnodies (Treny). Threnody 19, which is a rhetorical consolatio and exhortatio concluding the whole series, is presented as a dream in which the 
poet's mother describes heaven to convince her son that his deceased daughter is happier there:

W niebie szczere rozkoszy, a do tego wieczne

Od wszelakiej przekazy wolne i bezpieczne.

Tu troski nie panują, tu pracej nie znają,

Tu nieszczęście, tu miejsca przygody nie mają,

Tu choroby nie znajdzie, tu nie masz starości

Tu śmierć, łzami karmiona, nie ma już wolności.

Żyjem wiek nieprzeżyty, wiecznej używamy

Dobrej myśli, przyczyny wszelkich rzeczy znamy,

Słońce nam zawżdy świeci, dzień nigdy nie schodzi,

Ani za sobą nocy niewidomej wodzi,

Twórcę wszech rzeczy widzim w Jego majestacie,

Czego wy w ciele będąc próżno upatrzacie”. ${ }^{15}$

(But heaven hath purer, surer happiness,

Free from all intermingling of distress.

Care rules not here and here we know not toil,

Misfortune and disaster do not spoil.

Here sickness cannot enter nor old age,

And death, tear-nourished, hath no pasturage.

We live a life of endless joy that brings

Good thoughts; we know the causes of all things.

The sun shines on forever here, its light

Unconquered by impenetrable night;

And the Creator in his majesty

Invisible to mortals, we may see. ${ }^{16}$

Scholars have observed some similarities with Vergil's Aeneid and generally with pagan tradition, ${ }^{17}$ but Kochanowski's description does not seem to tally with the activities in the Elysium depicted by Vergil. We may think of it as a humanist way of expressing Christian ideas, as we can notice in Buchanan's paraphrase of Psalm 36 (35): 
At exsul animus, morte liber, patrium

Quum repetet limen sidereamque domum,

Illinc egestas et dolores exsulant,

Nemo feret votis non potiora suis.

Passim voluptas, pura passim gaudia,

Delicias largo flumine rivus agit.

Illinc perenni vita fonte profluit,

Vita gravis fati non resecanda manu.

Illinc fatiscent mentium caligines,

Quae modo sub tenebris pectora nostra premunt,

Vultuque radius purus effusus tuo,

Lumine nos purae cognitionis alet [11. 29-40]. ${ }^{18}$

(But when the exiled mind, free from death, reaches the Father's threshold and its starry home, its poverty and pains will be banished, and nobody will receive less than they ask for in their prayers. There will be delight and pure joy everywhere, a stream of pleasures will flow as from a broad river. From here, from this eternal source, life flows, and this life is not to be cut short by the hand of harsh Fate. Then the clouds on our minds, now afflicting our hearts with darkness, will be dispersed. The pure ray poured from Thy face will support us with the light of pure cognition.)

Incidentally, the passage is a striking amplification ${ }^{19}$ of the biblical material contained in two verses (9-10) of the Vulgate version: "inebriabuntur ab ubertate domus tuae et torrente voluntatis tuae potabis eos, quoniam apud te fons vitae, in lumine tuo videbimus lumen." ${ }^{20}$ Jan Kochanowski's Polish paraphrase was definitely closer to the Vulgate than to Buchanan ("we will be sated from the abundant generosity of Thy house, / and we will drink from the stream of Thy delights / With Thee is the fountain of life, our darkness / will be enlightened by Thee and soon we will see the day of true light." ${ }^{21}$ However, as a diligent reader and declared admirer of Buchanan's psalms, in this passage Kochanowski could have found an inspiration for his consolation of "the Humanist heaven" he depicts in the Threnodies. In Buchanan's paraphrase of Psalm 36, we can find the majority of the motifs Kochanowski used: heaven (the starry home), no labours, no pain, no poverty, "pure" and eternal delights, eternal life, a true cognition of reality and of the Absolute Himself. Certainly it should not escape our attention 
that even the very order of enumeration is almost the same in Kochanowski as in Buchanan: first, the human miseries, which are absent in paradise; second, the joys of endless life; and third, the light of God (although Buchanan is more Platonizing there and focuses more on the allegorical, epistemic light and "day," while Kochanowski also means the "physical" light).

Another of Kochanowski's inspirations for the Threnodies might have come from Buchanan's tragedy Iephtes sive votum. ${ }^{22}$ However, a detailed discussion of this influence may be difficult: Iephtes was translated into Polish by Jan Zawicki and printed in Kraków in $1587,{ }^{23}$ seven years after the editio princeps of Kochanowski's Threnodies, which had a very strong influence on Zawicki's translation of Iephtes. Kochanowski's phrases and rhymes filter through the Polish Iephtes even if (in comparison with the original Latin) there is no explicit reason for such borrowing. Hence the historian of literature is not able to be certain whether Zawicki reflected Kochanowski's hidden inspirations or simply rearranged the discourse ad modum Cochanovii (Kochanowski being the classic of Polish verse by that time), as for instance:

Buchanan, Iepthes:

Kochanowski, Treny:

Zawicki, Iepthes:
Hoc nemo nuper erat indulgentior, Nec liberorum quisquam amantior parens [11. 552-53]; ${ }^{24}$

Żaden ociec podobno barziej nie miłował Dziecięcia, żaden barziej nad mię nie żałował; ${ }^{25}$ (Probably no father loved a child more than I did, no one mourned more.)

Nikt przed tym dzieci własnych więcej nie miłował Nikt w więtszej wadze nie miał, więcej nie szanował. ${ }^{26}$ (Nobody ever loved his own children more, nobody esteemed or respected them more.)

However, there are many convergences between Buchanan's tragedy and the Threnodies that do not seem to concern just words, rhymes, or verse structures, but rather ideas and meanings; consequently, we may legitimately consider Iephtes a mental conspectus of many aspects of Kochanowski's work. Let us take a look at the Prologue, in which the Angel explains why God treated Jephthah the way He did: 
Humana sed mens nescia modum ponere

Rebus, secundis intumet successibus,

Quo plura hominibus contulit bonitas Dei,

Occaecat animos altior securitas

Vanoque fastu turgidos superbia

Stimulat inanis [11. 15-20]. ${ }^{27}$

(Yet the human mind cannot impose limits

To success but grows arrogant in good fortune.

The more God's goodness bestows on men,

the deeper the complacency which blinds their minds.

Empty arrogance fires them swollen

with superfluous pride. $)^{28}$

It could be seen as an inspiration for Threnody 18, which starts with:

My, nieposłuszne, Panie, dzieci Twoje,

W szczęśliwe czasy swoje

Rzadko Cię wspominamy,

Tylko rozkoszy zwykłych używamy.

Nie baczym, że to z Twej łaski nam płynie,

A także prędko minie,

Kiedy po nas wdzięczności

Nie uznasz, Panie, za Twe życzliwości. ${ }^{29}$

(We are thy thankless children, gracious Lord.

The good thou dost afford

Lightly do we employ,

All careless of the one who giveth joy.

We heed not him from whom delights do flow.

Until they fade and go

We take no thought to render

That gratitude we owe the bounteous sender.) $)^{30}$ 
This idea, which may also have Boethian roots, is further developed in the poem:

Yet keep us in thy care. Let not our pride

Cause thee, dear God, to hide

The glory of thy beauty:

Chasten us till we shall recall our duty. ${ }^{31}$

Kochanowski seems to use Buchanan's inspiration in the last but one poem in the whole series, placed immediately before the final consolation of Threnody 19. He is seeking a cause for God's judgment, accusing himself of a hybris, and is reconciled to Heaven's will. But the Threnodies reflect not only a personal tragedy, but also a family woe, and we have reasons to believe that the Polish poet could have looked at Buchanan's drama and his own experience from such a perspective. Thus, we find in Storge's speech many ideas that could well have germinated in the Threnodies:

O spes inanes! Festa nuptialia

Tibi parabam, nata, lucem cernere

Illam exspectabam, sorte quam te prospera

Auctam viderem liberis et coniuge

Claro beatam, te senectutis meae

Fore pollicebar columen ac solatium,

De te augurabar falsa frustra insomnia.

Nunc me insolenti saeviens ludibrio

Sortis furentis impotens immanitas

Felicitatis de supremo culmine

Deiecit, uno cuncta vertens impetu.

O ter beatos, liberis quis hosticus

Orbavit ensis, pestilens aut aeris

Lues, famesve... [11. 1126-39] ${ }^{32}$

(Alas for empty hopes! I was preparing

A wedding celebration for you, my daughter.

I longed to behold the day

When I might see you adorned by a happy fortune, 
Blessed by children and by a glorious husband.

I held put the promise that you will be

The stay and solace of my old age.

In vain did I nurture

deceiving dreams in your regard

But now the uncontrolled savagery of wild fate

rages with arrogant sport,

and has cast me down from the highest peak of blessedness,

overturning everything with a single assault.

Thrice blessed are those whom an enemy sword

Or a noxious plague from the air

Or famine has orphaned of their children $)^{33}$

The monologue corresponds with the bitterness caused by the premature death of Kochanowski's daughter, expressed in Threnody 7:

My little girl, 'twas to a bed far other

That one day thy poor mother

Had thought to lead thee, and this simple dower

Suits not the bridal hour. ${ }^{34}$

Another point we observe here which is also manifest in the Threnodies is the father's despair coming from the awareness of the loss of the person who was meant in future to repay all the duties of parental pietas, as expounded in Threnody 4:

For had God granted to her ample days

I might have walked with her down flowered way

And left this life at last, content, descending

To realms of dark Persephone, the all-ending ${ }^{35}$

Storge's exclamation about the spes inanes makes one think of Threnody 9 and its strong disillusion with the vain human hopes and intellectual aspirations; also, there is a vision in it of a fall from high to hard ground and-although in Kochanowski's poem the image is deeply embedded in Stoic commonplacesthe poet address Wisdom ironically: 
Oh, hapless, hapless man am I, who sought

If I might gain thy thresholds by much thought,

Cast down from thy last steps after so long,

But one amid the countless, hopeless throng ${ }^{36}$

The lines of Storge's speech I have quoted above may signal some of the ways prescribed to attain consolation enumerated in Threnody 19, where the poet's mother suggests that perhaps the death of Ursula is not to be understood as an utter disaster:

Why do we weep, great God? That with her dower

She bought herself no lord, that she might cower

Before upbraidings from her husband's kin?

That she knew not the pangs that usher in

The newborn child? And that she could not know,

Like her poor mother, if more racking woe

It were to bear or bury them ${ }^{37}$

Jephthah's story may also be considered as a catharsis of the lyrical subject, like Niobe's tragedy in Threnody 15, where the poet discusses whether our "private grief" does not "gain temperance" when we think of "mankind's evil chance." 38 If Storge suggests that the "thrice blessed" are those whose children were killed by an enemy's sword, the pestilent air, or famine, the desperate father may be supposed to think that his daughter, stricken by Death (the "breathing pestilence" ${ }^{39}$ ), "hath chosen well her part," ${ }^{30}$ better than that one who was sentenced to death by her own father, blinded by his cruel devotion. These examples, selected from among many others ${ }^{41}$ may demonstrate that Buchanan's "emotionally disturbing" $" 42$ tragedy had indeed contributed to the polyphonic structure of Kochanowski's Threnodies, in which Cicero played a major part; yet other ancient authors such as Ovid, and neo-Latin such as Petrarch, are echoed as well.

Another of Kochanowski's Polish poems, the humanist Christian hymn Czego chcesz od nas, Panie..., seems to have been inspired by another of Buchanan's tragedies, Baptistes. This hypothesis has been put forward by Roman Mazurkiewicz, who has indicated the similarities between Kochanowski's hymn and St. John's monologue in Buchanan..$^{43}$ As he emphasizes, not only 
do we observe a "convergence of single motifs, but also the whole sequence of mental, figurative or even phraseological analogies" containing hymnal and doxological elements proper to this convention and "subject to the general idea of manifesting God's perfection through the perfection of His creation." ${ }^{4}$ As Mazurkiewicz points out, both poets composed the laudes divinae using the same commonplaces in a very similar way and (in some cases) order. ${ }^{45}$ Suffice it for now to enumerate some correspondences. I shall have to quote some passages from Kochanowski's hymn in English translation, and substantiate the claim with the fifth stanza:

By Thy decree, all sundry flowers in Spring are born,

Likewise a grain-ear wreath shall Summer's head adorn.

Fresh wine and varied apples Autumn doth beget.

And only then the Winter comes, when all is set. ${ }^{46}$

This stanza seems to match the following passage from Baptistes' speech (and to correspond with Horace's Diffugere nives as well):

Iussu tuo ver pingit arva floribus,

Fruges dat aestas, fundit autumnus merum,

Hiems pruinis vestit albicantibus. ${ }^{47}$

(At your command the spring decks the fields with blossoms,

Summer proffers harvest, autumn pours forth wine,

And winter clothes the mountains with whitening frost. $)^{48}$

But the similarities are also perceptible through the presence of the commonplace vicissitudo rerum, as in Buchanan: "in aequor curva volvunt flumina / Moles aquarum, mare reciprocat vices / Noctem Diana, Phoebus incendit diem"49 ("Winding rivers roll down to the sea masses of waters, the sea's tides ebb and flow. Diana fires the night and Phoebus the day" ${ }^{50}$ ) and in Kochanowski:

The seas abide within their shores by Thy command, For they dare not outside the drafted bounds expand; The days and eves observe their timing all year round; And all the brooks and streams in water now abound. ${ }^{51}$ 
If Buchanan's Baptistes did influence Kochanowski's hymn, the Polish poet would have to have read a handwritten version of the tragedy, since Baptistes was not published before 1577 and Kochanowski's hymn had been written probably in France and was published first in 1561 or 1562. Although unable to confirm the hypothesis that the "Carolus" of Kochanowski's Elegy III 8 was Utenhove, this would reinforce the conjecture that a humanist friend may have had his part in introducing Kochanowski to the Paris milieu and turning his attention to Buchanan.

It would be difficult to give an all-embracing description of Kochanowski's Christian Latin, but his Ode 2, In deos falsos, is a good example and probably owes much to Buchanan's Iephtes and paraphrases of the Psalms. It is particularly striking for its last two stanzas, which have the structure of a hymnic ode and present the true worship of God that springs from a pure and contrite heart:

At tu, magne parens orbis et arbiter

Naturae, veluti principio cares,

Sic expers quoque finis

Vives omnia saecula.

Te nos non pecudum sanguine, sed prece

Casta prosequimur, cordeque simplice;

Tu placatus amicis

Adversa omnia mollies. ${ }^{52}$

(And Thou, O great Father of the world and Ruler of Nature,

Who hast no beginning

and no end,

Thou shalt live for all ages.

We follow Thee-not with the blood of animals,

but with pure prayer and a simple heart.

And when Thou art placated,

Thou shalt soften all the hardships suffered by Thy friends.)

The contrast between the blood sacrifice and the contrite mind is presented antithetically in Psalm 51 (50), 18-19. In comparison with the Vulgate, Buchanan's version of this Psalm ${ }^{53}$ emphasizes the sanguis and placare: 
Victimae si te caperent, dedissem

Victimam, sed te neque sanguis hirci

fusus aut sacris holocausta placant addita flammis.

Paenitens fraudum scelerumque pectus

Spiritus fracti, mala cor perosum,

Haec Deum placant.... [11. 65-71]

A similar situation is shown in Iephtes when the Priest "argues against the sacrifice with all his rhetorical power" 54 :

Nostro non litatur victimis

Deo cruentis, bubulove sanguine

Polluta nullo corda sed contagio

Et mens recocta veritate simplice

Illi offerenda et casta conscientia ${ }^{55}$ [11. 895-99]

(Our God is not offered gory victims

or the blood of cattle;

but hearts defiled by no pollution,

a mind refined by ingenuous truth,

and a chaste conscience are to be offered to him. $)^{56}$

In Buchanan's paraphrase of Psalm 102 we find a description of God's eternity which seems akin to Kochanowski's image:

At te perpetuis saecula saeculis

Nectentem, volucris non fuga temporis

Carpit, nec memorem nominis obruet

Famam posteritas tui. [11. 37-40]

An tu, qui fueras, semper es atque eris,

In teipsoque habitas, nec varias vices

Decurso patiens tempore, permanes

Metae saecula nescia. [11. 93-96] $]^{57}$ 
(But the flight of winged time affecteth not Thee

Who joinest ages to ages without end,

Nor shall the age to come bury

The memorable fame of Thy renown ${ }^{58}$

But Thou, who hast been, always art and shall be

And Thou livest in Thy self,

Not suffering various vicissitudes from the fleeting of the time,

Thou endures to ages that know no end.)

There are other analogies with Buchanan's work in Kochanowski's Latin verse, although in some cases, neo-Latin poetry being a kind of mosaic, one cannot be certain whether they are a true literary dialogue or are due to a humanist fashion. For instance, in his Foricenia (a collection of epigrams), the Polish poet expresses his ideal of the poeta ebrius as opposed to the staid and sober scribbler:

Nugae profecto sunt merae,

Meraeque, Petre, fabulae,

Quae de volucris fonte equi

Vates vetusti garriunt.

Vinum est, poetas quod facit

Et blanda dictat carmina,

Aquam bibentibus nihil

Insigne Musa subicit.

Horum locuples, o Petre,

Testis vel ipse sim tibi,

Qui sobrius possum nihil,

Nisi immerentem dentibus

Cunctator unguem rodere .... ${ }^{59}$

(Those are pure trifles

And pure fables, Peter,

That ancient poets prattle

Having drunk from a gushing horse-fountain.

It is wine that makes you a poet

And dictates charming verses. 
The Muse does not suggest anything excellent

To water-drinkers.

I may be a faithful witness

To you, Peter.

While sober, I can do nothing

Except delay

and bite my innocent nails.)

I would like to point out some ideological similarities of this foricenium with Buchanan's Elegy I, composed between 1528 and 1531; I am not saying that they are necessarily an influence, ${ }^{60}$ but rather evidence that both poets contributed to the circulation of ambient ideas. Both Kochanowski's epigram and Buchanan's elegy argue against the kind of poetry that can be described as "pedantic" or "academic" as opposed to "inspired," as is clear in Kochanowski's epigram. This dichotomy dates back to the Hellenistic period and is connected with particular figurative expressions - the hydropotae (water-drinking) poets and the oinopotae (wine-bibbers). ${ }^{61}$ A "pedantic" poet is able only to scratch his head and bite his nails, which means that he is helpless and his labour is futile, as Horace shows. ${ }^{62}$ We can find a similar image of "dull" poetic activity in Buchanan's elegy:

Ite leves nugae, steriles valete Camenae

Grataque Phaebeo Castalis unda choro! ...

Quaerite quem capiat ieiuna cantus in umbra,

Quaerite qui pota carmina cantet aqua! ...

Pervigil in lucem lecta atque relecta revolves

Et putri excuties scripta sepulta situ,

Saepe caput scalpes et vivos roseris ungues

Irata feries pulpitum saepe manu

Hinc subitae mortes, et spes praerepta senectae,

Nec tibi fert Clio, nec tibi Phoebus opem ... ${ }^{63}$

(Go away, slight trifles, farewell, sterile Muses!

Go away, water of Castalia, delight of Apollo's choir! ...

Seek another, who will be pleased with singing in a hungry den,

Seek another, who will sing inebriate songs having drunk water! ... 
Even if you stay awake until dawn, reading, rereading And shaking off the books, buried in a putrid place, Even if you often scratch your head and bite your nails, And often beat the desk with your furious hand, The result may be only a sudden death without any hope of old ageNeither Clio nor Phoebus will help you.)

Although Buchanan focuses more on the material misery ${ }^{64}$ of his "exile" life, comparable with Ovid's experience, ${ }^{65}$ it would be not unreasonable to suppose that both poets appear also to reflect the figurative dimension mentioned above, especially if we think of the special career of Bacchus, who was regarded during the Renaissance period as a source of inspiration, especially in Italy and France. ${ }^{66}$

It is also possible that Kochanowski may have assimilated the leading trends in European culture and poetry during his peregrinations in Italy and France. The same might be speculated about his occasional court poetry which assumes a bucolic form. There are examples of bucolic themes and tendencies both in Buchanan's and in Kochanowski's oeuvre, and in both it may be an echo of the French pastoralism which, as Raymond Monelle points out, "took root in the courtly and occasional poems of Ronsard." ${ }^{67}$ Perhaps we should bear this cultural current in mind when dealing with Kochanowski's Dryas Zamchana and Pan Zamchanus, two short poetic idylls which were in fact panegyrics praising Stephen Báthory recited in the King's presence when he was staying at Zamech for a hunt organized in May, 1578 by Jan Zamoyski, Lord Starost of Zamech and Chancellor of the Kingdom of Poland. The "rustic gods", a dryad, Pan, and satyrs recommend the joys of life in the forest and the excitement of the chase, and offer their gifts to the king, as expressed in Pan's soliloquy:

Pan ego sum, cui silva domus, cui fistula cordi

Nympharumque leves sublustri nocte choreae.

Hos Satyros dicunt: gens nimirum haec quoque silvis

Dedita, sed natura rudis, moresque petulci....

Quod superest, haec silvicolae munuscula divi, ...

Nec tu poma nova decussa ex arbore, neve

Dedignare pyra, et pulchris cerasa addita prunis. ${ }^{68}$ 
(I am Pan; the wood is my home. I like my pipe

And the light dances of Nymphs on a moonlit night.

And those there are called Satyrs; This race is also much addicted to the woods, But their nature is primitive and their demeanour aggressive ...

What remains are these little gifts from the forest god,...

Do not disdain these fresh apples shaken down from the tree, nor the pears, the cherries and the beautiful plums.)

Buchanan uses a similar convention in his Pompae deorum rusticorum, performed at Mary Stuart's court on the occasion of James's christening. In this text there is also enthusiasm for the hunt and the contrast between the forest's profundity and the noise of the city:

Silvestres tibi satyri dona

Damus agrestia, ruris alumni

Volucres laeti ruris alumnos,

Et praevertere solitos ventos

Male confisos pedibus cervos.

At cum veniet robur ab annis

Capies acribus ipse Molossis

Capreas, claudes retibus apros.

Disces strepitu saepe quod urbis

Iure anteferat rura voluptas. ${ }^{69}$

(We, the forest Satyrs

Are giving you our gifts from the forest.

As children of the country, we are happy to give you the birds, which are also children of the countryside,

And the deer,

accustomed to outrun the unpredictable winds.

As you grow stronger,

You will try deer-hunting with dogs

And trapping wild boars in a net,

And you will learn to prefer the rural delights

To the noise of the city.) 
One of Kochanowski's odes published in Lyricorum libellus (1580) is a poem entitled In equum, an invective against the poet's clumsy horse. In its first part the poet plays intertextually with Horace's Ode II 13 on the accursed tree that almost killed him. The horse which is the addressee of Kochanowski's ode did much the same:

Quadrupedum pudor et Seiani infausta caballi

Progenies, certissima pestis

Exitiumque altoris heri; quae premia tristis

Vecturae tibi nomine solvam?

Non tu ad Pisaeae natus certamina palmae,

Non circo sudare frequenti;

Non tu audire tubas, non obvius ire sagittis,

Aut densas perrumpere turmas.

Magna loquor; neque tu visendis fidus amicis

Vector, inoffensumve patenti

Alternare pedem campo, dominumque paterna

Incolumem sub tecta referre.

Quam pene ad Stygias vexti me, perfide, valles $[\ldots]^{70}$

(O shame of quadruped animals! O unlucky offspring of Sejanus'horse!

$\mathrm{O}$ certain plague and death

of your nourisher and master! What reward

should I give you for your harsh transportation?

You are not born for the Pisean course and palm,

nor to sweat in a circus.

You are not born to hear the war-trumpets, to go forward against the arrows,

to break through a dense line of troops.

How great are my words! You are not even a faithful vehicle

to carry your master to visit his friends

and let him come back home safe and sound,

and to walk in an open space without harm to your feet!

O perfidious creature, you have nearly carried me into the Stygian valley!)

If we are trying to read neo-Latin poetry through the lens of motifs and ideas, this ode looks like an antithetic counterpart of Buchanan's De equo elogium. 
Both poems owe much to rhetorical strategy and commonplaces. The expressions of disapproval and of praise are the two categories or even the two poles of the epideictic speech. ${ }^{71}$ As Philip Ford indicates, De equo elogium owes many of its elements to Ravisius Textor's Specimen epithetorum. ${ }^{72}$ Its first edition was published in 1518; reprinted many times, the work was "one of most universally scoured linguistic resources of the $16^{\text {th }}$ cent[ury]," ${ }^{73}$ as Ann Moss underlines. Let me bring the poems into dialogue with each other, even if Kochanowski meant no such thing. The text of Silvae 6 is as follows:

Cetera rerum opifex animalia finxit ad usus

Quaeque suos, equus ad cunctos se accommodat unus.

Plaustra trahit, fert clitellas, fert esseda, terram

Vomere proscindit, dominum fert, sive natatu

Flumina, seu fossam saltu, seu vincere cursu

Est salebras opus, aut canibus circumdare saltus,

Aut molles glomerare gradus, aut flectere gyros,

Libera seu vacuis ludat lascivia campis.

Quod si bella vocent, tremulos vigor acer in artus

It, domino et socias vomit ore et naribus iras,

Vulneribusque offert generosum pectus, et una

Gaudia, maerores sumit ponitque vicissim

Cum domino; sortem sic officiosus in omnem,

Ut veteres nobis tam certo foedere iunctum

Crediderint mixta coalescere posse figura

Inque Pelethronis Centauros edere silvis. ${ }^{74}$

(The Creator of the universe made all other animals each for their own individual purposes, but the horse alone adapts itself to all purposes. He draws wagons, bears pack-saddles and bears chariots, he cleaves the ground with the ploughshare and bears his master, whether he must swim across rivers, or leap ditches, or gallop over ruts, surround woodlands with the hounds, gently trot, or wheel round, or whether unrestrained frolicking disports on the open plain. But if war summons, a keen force enters his trembling limbs, he breathes out rage from his mouth and nostrils in common with his master, he offers his brave breast to wounds, and together with his master takes on or loses in turn joy and sorrow. So dutiful in every task is he that the Ancients believed that, as he is united to us 
in such a definite bond, he can mingle in a hybrid form and produce Centaurs in the Pelethronian woods. $)^{75}$

Ford discusses the poem in detail in the context of similarities with ancient authors quoted in Ravisius's Specimen (fo. 126-28): Silius Italicus, Columella, Vergil, Lactantius, and Sabellicus. ${ }^{76}$ Exploiting this treasury, Buchanan demonstrates the versatility of the horse, which is able "to do many things well." "77 Interestingly, while "Buchanan's horse" bears his master, even if he has to cross a river, or gallop over rough patches of road, or leap a ditch, or whatever, Kochanowski's horse, on the contrary, is able to do nothing except to throw his master, even when "gently trotting" (or walking) on the open plain. $\mathrm{He}$ is unable, of course, to expose his breast to arrows, being unsuitable for war (and also for domestic purposes). Is Kochanowski playing with Buchanan, or is he merely turning the loci communes of praise, drawn from wherever possible, upside down and inside out?

Either way, it seems that the Scottish poet, held in so high esteem by his contemporaries, had a strong influence on Kochanowski's work, and this influence was not limited to the Psalter. Regardless of whether the mysterious Carolus (the poet's cicerone in France) was Utenhove or not, the beginning of Kochanowski's interest in Buchanan's work may be connected with the social network of friends such as Dudith or Tęczyński who were on familiar terms with the Flemish humanist. Not only the circulation of books, humanist ferment etc., but also private friendships played a role in the communication of ideas in the Respublica litterarum.

\section{Notes}

1. Marian K. Dziewanowski, Poland in the Twentieth Century (New York: Columbia University Press, 1977), p. 15.

2. As Tadeusz Ulewicz emphasizes, "Just as in the Trecento the great Florentine trinity, Dante, Petrarch and Boccaccio, had determined once and for all the future linguistic pattern of Italian literature, so-two centuries later-in Poland it was Jan Kochanowski who settled the direction of development of modern literary Polish both in its linguistic and its formal and artistic aspects, ushering the language into 
the arena of European literature.” Tadeusz Ulewicz, Jan Kochanowski of Czarnolas, trans. Teresa Bałuk-Ulewiczowa (Kraków: Collegium Columbinum, 2002), p. 33.

3. Adam Karpiński, "Renaissance," trans. Daniel Sax, in Ten Centuries of Polish Literature, ed. Grażyna Borkowska et al. (Warsaw: IBL, 2004), p. 55.

4. It is mainly the question of innovative richness of versification. As Manfred Kridl says, "We find in the psalms an immense wealth and variety with regard to the length of the line and the structure of the stanza (there are approximately 30 kinds), to rhythm and rhyme. The richness of Kochanowski's poetic devices makes the forms of earlier Polish poetry look poor by comparison." Manfred Kridl, $A$ Survey of Polish Literature and Culture, trans. Olga Scherer-Virski (New York: Columbia University Press, 1956), p. 69.

5. The first scholar to have suggested this identification was Stanisław Kot in Jana Kochanowskiego podróże i studia zagraniczne, in Studia staropolskie. Ksiega ku czci Aleksandra Brücknera (Kraków: Krakowska Spółka Wydawnicza, 1928), pp. 40417); the hypothesis was questioned by Stanisław Windakiewicz in Jan Kochanowski (Kraków: Krakowska Spółka Wydawnicza, 1930). Willem Janssen, in Charles Utenhove, sa vie et son oeuvre (1536-1600) (Maastricht: Van Aelst, 1939), p. 38, asserts that there is no evidence of any contact between Utenhove and Kochanowski, for "le nom de ce Polonais n'est pas cité une seule fois dans l'oeuvre d'Utenhove." However, Kochanowski, who was six years older than Utenhove, but had not yet published any poetry (if we do not count the epitaph for Erazm Kretkowski engraved in St. Anthony's in Padua in 1558 and printed in Scardeonius's De sepulchris insignibus exterorum Patavii iacentium, added to De antiquitate urbis Patavii et claris civibus Patavinis libri tres, Basel, 1560), may have seemed a "nobody"-a poor student from Poland, recommended to him by his friend Andrew Dudith. This friendship is proved in Gérard-Marie Imbert's sonnets; see Léonce Couture, Trois poétes condomois du 16e siècle: Études biographiques et littéraires sur Jean du Chemin, Jean-Paul de Labeyrie, Gérard-Marie Imbert (Bordeaux, C. Lefebvre, 1877), p. 78. In recent studies, see Andrzej Borowski, Iter Polono-Belgo-Ollandicum: Cultural and Literary Relationships between the Commonwealth of Poland and the Netherlands in the 16th and 17th Centuries (Kraków: Księgarnia Akademicka, 2007), p. 66: “The question has not [been re]solved so far, but the hypothesis of Jan Kochanowski's personal and visual acquaintance with Flanders, especially with Gent, seems reasonable and acceptable." Lately, a new hypothesis has been suggested for Carolus's identity. Jörg Schulte supposes that the addressee of Kochanowski's El III 8 might have been Carolus Langius (Charles Delanghe or de Langhe, 1521-73), in Jan Kochanowski 
i renesans europejski. Osiem studiów (Warszawa: Neriton, 2012), pp. 289-308. The hypothesis seems reasonable and well-argued, but appears to complicate the matter. If the "Carolus" who accompanied Kochanowski during his journey from Padua to France and Belgium, was actually Langius, a fervent Catholic, it seems less probable that he could be the person who introduced the Polish poet to Buchanan's milieu. However, the introduction was possible without any intervention from Carolus, through the agency of Andreas Dudith, for example.

6. Ioannes Cochanovius, Elegiarum libri IV, [...] Foricoenia sive Epigrammatum libellus (Cracoviae: Officina Lazari, 1584), Lr.-Lv.

7. Unless otherwise indicated, the translations are mine.

8. Maurice Dullaert, "Un ami gantois de la Pléiade," Le Cahier des arts (juillet) 1959, pp. 1493-1501.

9. See Ian Dalrymple McFarlane, "George Buchanan and France," in Studies in French Literature presented to H. W. Lawton by colleagues, pupils and friends, ed. H. W. Lawton et al. (Manchester: Manchester University Press, 1968), p. 235.

10. As McFarlane says, "Italy produced two contributors, Flaminio and Rapizzo, Germany was represented by Eobanus Hessus, France faute de mieux, as the editor tactfully explained, by Salmon Macrin, and Scotland by Buchanan." ("George Buchanan and France," p. 235).

11. Cochanovius, Elegiarum libri IV, pp. 152-53.

12. See E. Buszewicz, "Buchanan in Poland: Facts, Questions, and Paradoxes," in Acta Conventus Neo-Latini Bonnensis, ed. Rhoda Schnur, Perrine Galand-Hallyn, et al. (Tempe: MRTS, 2006), p. 222.

13. He did not esteem Hessus's paraphrases composed in elegiac distich; in his opinion, expressed in a letter to Stanisław Fogelweder, "Hessus did it within three years, however, he did it badly." The letter (in Polish), written in 1571, was published first by Włodzimierz Stanisław Broel-Plater, in Zbiór pamiętników do dziejów polskich (Warszawa: Drukarnia Gazety Codziennej, 1858), vol. 1, pp. 231-33 and is republished in many collective editions of Kochanowski's works.

14. As Roger Green emphasizes, examining Psalm 121 (120): "Mention of war ... again recalls the situation of David, but could actually well apply to Everyman. Buchanan's poem certainly does not ignore the original context, but he creates a poem applicable to contemporary Christians ..., and, indeed, a comfort to himself.” Roger Green, “George Buchanan’s Psalm Paraphrases in a European Context," in Scotland in Europe, ed. Ian Rankin and Tom Hubbard (Amsterdam: Rodopi, 2006), p. 36. 
15. Jan Kochanowski, Dzieła polskie, ed. Julian Krzyżanowski (Warszawa: PIW, 1967), vol. 2, p. 81.

16. Jan Kochanowski, Poems, trans. Dorothea Prall (Berkeley: University of California Press, 1928), p. 48 (hereafter cited as Prall).

17. Mieczysław Hartleb, Nagrobek Urszulki: Studium o genezie i budowie Trenów Jana Kochanowskiego (Kraków: Krakowska Spółka Wydawnicza, 1927), pp. 131-32; A. Nowicka-Jeżowa, “Sen życia w 'Trenie XIX’ Jana Kochanowskiego," Rocznik Towarzystwa Literackiego imienia Adama Mickiewicza 32 (1997), p. 54.

18. The texts of Buchanan's works are from George Buchanan, Opera omnia ad optimorum codicum fidem summo studio recognita et castigata, vol. 2 (Lugduni Batavorum [Leyden], 1775).

19. Elwira Buszewicz, "Homo Exsul as the Lyric Persona of Buchanan's Psalms," in George Buchanan, Poet and Dramatist, ed. Philip J. Ford and Roger P. H. Green (Swansea: The Classical Press of Wales, 2009), pp. 98-99.

20. The King James Version (Ps 36) renders it: "They shall be abundantly satisfied with the fatness of thy house; and thou shalt make them drink of the river of thy pleasures. For with thee is the fountain of life: in thy light shall we see light."

21. In the original Polish: "Hojnością domu Twego będziem nasyceni / I strumieniem rozkoszy Twoich napojeni; / U Ciebie zdrój żywota, Ty nasze ciemności / Rozświecisz, a wnet ujźrzem dzień prawej światłości.” See Jan Kochanowski, Dzieła polskie, vol. 1, p. 372.

22. Iephthes sive votum. Tragoedia auctore Georgio Buchanano Scoto (Paris: apud Guillelmum Morellum, 1554).

23. Jan Zawicki, Iephtes: Tragoedia (Cracoviae: Officina Lazari), 1587.

24. Buchanan, Opera omnia, p. 193.

25. Threnody 12, lines 1-2. Prall renders it, "I think no father under any sky / More fondly loved a daughter than did I, / And scarcely ever has a child been born / Whose loss her parents could more justly mourn” (p. 35).

26. Zawicki, C3r.

27. Buchanan, Opera omnia, p. 181.

28. Buchanan, Tragedies, ed. and trans. P. Sharatt and P. G. Walsh (Edinburgh: Scottish Academic Press, 1983), p. 64.

29. Kochanowski, Dzieła polskie, vol. 2, p. 78.

30. Prall, p. 44.

31. Prall, p. 44.

32. Buchanan, Opera omnia, p. 106. 
33. Sharatt and Walsh, p. 87.

34. Prall, p. 30.

35. Prall, p. 30.

36. Prall, p. 32.

37. Prall, p. 48.

38. Prall, p. 38.

39. Prall, p. 28 (Threnody 5).

40. Prall, p. 48 (Threnody 19).

41. A closer reading of Iephtes may reveal more similarities of this kind. For instance, when Symmachus argues that "Non transigenda temere res est tam gravis, / Turbata caeco dum tumultu mens furit, / Compone tete, cum quiescet impetus, / Et liber animus sana consilia audiet, / Una cum amicis cuncta statuis libere" (lines 755-58), the reader may think of the idea of aegritudo mentis (manifested also in Buchanan's Paraphrasis psalmorum), a sickness of the mind, and especially of reason, which is also strongly present in the Threnodies ("Poor philosophy, so late / Of its power wont to prate, / Showeth its incompetence / Now that joy proceedeth hence. // Sometimes still it strives to prove / Heavy care it can remove; / But its little weight doth fail / To raise sorrow in the scale." Prall, p. 42 (Threnody 17).

42. See Robert Crawford, Scotland's Books: A History of Scottish Literature (Oxford: Oxford University Press, 2009), p. 130.

43. Roman Mazurkiewicz, "Do genezy hymnu Jana Kochanowskiego Czego chcesz od nas, Panie, za Twe hojne dary", Ruch Literacki, 1990, issue 4/5, pp. 293-308.

44. As expressed (in Polish) in the electronic version of Mazurkiewicz's article (note 43), same title as above, accessed December 14, 2012, http://staropolska.pl/renesans/opracowania/Hymn_01.html.

45. As Mazurkiewicz observes, lines 13-20 of Kochanowski's hymn have their precise equivalents in Buchanan's text; and single motifs, slightly varied, are repeated in lines $1-12$.

46. See Jarek Zawadzki, ed. and trans., Selected Masterpieces of Polish Poetry (Shenzhen: BookSurge, 2007), p. 13. For the literal translation (and also the Polish original) see Norman Davies, God's Playground: A History of Poland (New York: Oxford University Press, 2005), vol. 1, p. 119.

47. Buchanan, Opera omnia, p. 236. See also Ovid, Met. II 27-30: "Verque novum stabat cinctum florente corona, / stabat nuda Aestas et spicea serta gerebat, / stabat et Autumnus calcatis sordidus uvis / et glacialis Hiems canos hirsuta capillos" (Young Spring was there, with a floral crown, Summer, all unclad with garland 
of ripe grain; Autumn was there, stained with the trodden grape, and icy Winter, with white and bristly locks), from Ovid, Metamorphoses, trans. Frank Justus Miller, LCL 42 (Cambridge: Harvard University Press, 1951), vol. 1, pp. 62-63). See also Ov., Rem.am. 188-89: "Poma dat autumnus: formosa est messibus aestas / Ver praebet flores: igne levatur hiems." (Autumn brings fruit : summer is fair with harvest : spring gives flowers ; winter is relieved with fire), from Ovid, Art of Love and Other Poems, trans. J. H. Mozley, revised by G. R. Goold, LCL 232 (Cambridge: Harvard University Press, 1999), pp. 190-91. But the ancient authors don't avail themselves of this image to praise God, nor do any of them say that Autumn "gives wine."

48. Sharatt and Walsh, p. 149.

49. Buchanan, Opera omnia, p. 236.

50. Sharatt and Walsh, p. 149.

51. Zawadzki, ed., p. 13.

52. Ioannes Cochanovius, Lyricorum libellus (Kraków: Officina Lazari, 1580), A3v.

53. The Vulgate has: "Quoniam si voluisses sacrificium, dedissem utique; holocaustis non delectaberis. Sacrificium Deo spiritus contribulatus; cor contritum et humiliatum, Deus, non despicies.”

54. Lois E. Bueler, The Tested Woman Plot: Women's Choices, Men's Judgments and the Shaping of Stories (Columbus: Ohio State University Press, 2001), p. 53.

55. Buchanan, Opera omnia, p. 200.

56. Sharatt and Walsh, p. 82.

57. Buchanan, Opera omnia, pp. 114-15.

58. George Buchanan, Paraphrase of the Psalms of David, translated into English prose, ed. and trans. A. Waddel (Edinburgh: J. Robertson, 1772), pp. 241-42.

59. Cochanovius, Elegiarum libri IV, p. 156.

60. As Estelle Haan has demonstrated (and Virginia Chaney suggested), there are more affinities between Buchanan's elegies and those of Milton, so that one has reasons to assume that the structural arrangement of Milton's elegies follows that of Buchanan's Elegiarum liber. As in Buchanan, so in Milton the first elegies are about the "dull academic life." See Haan, "Two Neo-Latin Elegists: Milton and Buchanan," Humanistica Lovaniensia 46 (1997), pp. 268-73.

61. See Peter E. Knox, "Wine, Water and Callimachean Polemics," Harvard Studies in Classical Philology 89 (1985), pp. 107-19.

62. "in versu faciendo / saepe caput scaberet vivos et roderet unguis" (As he wrought his verse, he would oft scratch his head and gnaw his nails to the quick), Hor. Sat 
I 10, 11. 70-71 from Horace, Satyres, Epistles and Ars Poetica, trans. H. Rushton Fairclough, LCL 194 (Cambridge: Harvard University Press, 1942), pp. 120-21.

63. Buchanan, Opera omnia, pp. 301-02.

64. See Haan, p. 272.

65. "non haec immodico contraxi damna Lyaeo: / scis, mihi quam solae paene bibantur aquae" (I have not caught these illnesses by excessive consumption of wine: you know that I hardly drink anything but water), from Ovid, Epistulae ex Ponto, book 1, ed. and trans. Jan Felix Gaertner (Oxford: Oxford University Press, 2005), p. 88. But, according to Gaertner's commentary (p. 517), Ovid rejects an excessive drinking of wine, as he declares himself in Ex Ponto I 5, 45: "Nec iuvat in lucem nimio marcescere vino" (Neither does it delight me to fade away until daylight in consuming too much wine), pp. 70-71.

66. J. F. Moffitt's chapter entitled "The Neoplatonic Bacchus of the Renaissance," in Moffitt's Inspiration: Bacchus and the Cultural History of a Creation Myth, Philosophy of History and Culture 22 (Leiden: Brill, 2005), p. 129-80. See also Evelien Chaies, “Tromper les plus clair-voyans: The Counterfeit of Precious Stones in the Work of Rémy Belleau," in On the Edge of Truth and Honesty: Principles and Strategies of Fraud and Deceit in the Early Modern Period, ed. T. van Houdt et al., (Leiden: Brill, 2002), pp. 207-08.

67. Raymond Monelle, The Musical Topic: Hunt, Military and Pastoral, Musical Meaning and Interpretation (Bloomington: Indiana University Press, 2006), p. 190.

68. [Jan Kochanowski], Dryas Zamchana Polonice et Latine, Pan Zamchanus Latine (Lwów, 1578), B2r.-B2v.

69. Pompae Deorum Rusticorum dona ferentium Iacobo VI et Mariae, matri eius, in coena quae Regis baptisma est consecuta, in Buchanan, Opera omnia, p. 404.

70. Cochanovius, Lyricorum libellus, $\mathrm{C} \mathrm{r}$.-Cv.

71. See Andrea Rotstein, The Idea of Iambos (New York: Oxford University Press, 2010), pp. 63, 93. See also B. Vickers. Classical Rhetoric and English Poetry (London-New York: Macmillan, 1989), p. 69.

72. Philip Ford, George Buchanan: Prince of Poets. With an Edition (Text, Translation, Commentary) of the Miscellaneorum liber, ed. Philip J. Ford and William S. Watt (Aberdeen: Aberdeen University Press, 1982), p. 42.

73. Ann Moss, Printed Commonplace-Books and the Structuring of Renaissance Thought (Oxford: Oxford University Press, 1996), p. 172. See also Ian Darlymple McFarlane, "Reflections on Ravisius Textor's Specimen epithetorum," in Classical 
Influences on European Culture: AD 1500-1700, ed. Robert Ralph Bolgar (Cambridge: Cambridge University Press, 1976), pp. 81-90, and Walter J. Ong, “Typographic Rhapsody: Ravisius Textor, Zwinger and Shakespeare," in Ong's Interfaces of the Word: Studies in the Evolution of Consciousness and Culture (New York: Cornell University Press, 2012), pp. 147-88.

74. Buchanan, Opera omnia, p. 340.

75. Translation quoted from Ford, George Buchanan: Prince of Poets, p. 42 . See also the verse rendering by Crawford, p. 127.

76. Ford, George Buchanan: Prince of Poets, pp. 42-43.

77. Crawford, p. 127. The author goes further and associates this horse's versatility with the "Renaissance man," exemplified by Buchanan himself. In a surprising and elegant way, Crawford goes on to discuss Buchanan's poetic versatility, craft, and eloquence. 